\title{
The Immune Microenvironment in Breast Carcinoma: Predictive and Prognostic Role in the Neoadjuvant Setting
}

\author{
Nahla M. Badra,b Fedor Berditchevskia ${ }^{a}$ Abeer M. Shaaban ${ }^{a, c, d}$ \\ ${ }^{a}$ Institute of Cancer Sciences and Genomics, University of Birmingham, Birmingham, UK; ${ }^{b}$ Department of \\ Pathology, Faculty of Medicine, Menoufia University, Shebin El-kom, Egypt; ' ${ }^{C}$ Queen Elizabeth Hospital Birmingham, \\ Birmingham, UK; ${ }^{d}$ Department of Pathology, University of Tanta, Tanta, Egypt
}

\section{Established Facts}

- The immune system is responsible for the maintenance of tissue homeostasis by initiating inflammatory reactions that involve the activation of innate and adaptive immune cells.

- In cancer, immune responses that aim to eliminate the tumour are elicited. However, the neoplastic cells may escape the immune control through immune-editing which depends on both tumour and immune cell interactions.

- New therapies have the potential to reactivate the immune response against cancer, e.g., in melanomas and lung cancer, and this is associated with improved outcomes.

\section{Novel Insights}

- Immune cell subpopulations, especially tumour-infiltrating lymphocytes (TILs) in the breast carcinoma microenvironment, can influence the tumour response to various neoadjuvant chemotherapy regimens, particularly in triple-negative and HER2-positive breast cancers.

- Recognition of TIL subtypes and locations in relation to tumour cells in breast carcinoma are promising for the development of more effective options of targeted therapy.

- The International TILs Working Group recommends the assessment of TILs on H\&E sections. Stromal TILs should be analysed excluding necrotic and crushed areas. Immunohistochemical and digital assessments of TILs are currently limited to the research setting.

\section{Keywords}

Breast carcinoma · Tumour-infiltrating lymphocytes ·

Neoadjuvant chemotherapy · Tumour-infiltrating macrophages - Tumour-infiltrating neutrophils ·

Tumour-infiltrating dendritic cells · Pathological complete response

\begin{abstract}
The prognostic value of the immune cell infiltrate in the breast carcinoma microenvironment is still uncertain. We reviewed published articles analysing the infiltration of inflammatory cells in the microenvironment of breast carcinoma. Data revealed the importance of infiltration of these immune cells in the prognosis of breast carcinoma, particularly
\end{abstract}

karger@karger.com
www.karger.com/pat
Karger

Dr. Abeer M. Shaaban

Histopathology, Queen Elizabeth Hospital Birmingham

Mindelsohn Way, Edgbaston

B15 2GW Birmingham (UK)

E-Mail Abeer.Shaaban@uhb.nhs.uk 
the triple-negative and HER2-positive phenotypes. Tumourinfiltrating lymphocytes and their subtypes play a fundamental role in predicting the pathological complete response $(p C R)$ to neoadjuvant chemotherapy. More research aiming to dissect a complex network of communication between cancer cells and other cellular components of the tumour microenvironment is necessary to develop more effective therapeutic approaches.

(c) 2019 S. Karger AG, Basel

\section{Introduction}

It has long been recognised that the tumour microenvironment is likely to play an important role in tumour development and progression. Significant progress has been made in the last few decades in describing the cellular composition of this microenvironment and its function in different types of cancer, including breast carcinoma. There is growing interest in exploring its prognostic and predictive roles in response to various types of therapy, especially chemotherapy, which can be more efficient after successful reactivation of the host's immune surveillance [1]. In the adjuvant setting, a high infiltration by lymphocytes, either into the tumour tissue or its surrounding stroma, has been significantly associated with a good prognosis in patients with estrogen receptor (ER)-/ HER2-negative breast cancer treated with anthracycline only versus a combination of doxorubicin + docetaxel chemotherapy [2]. An improved clinical benefit of adjuvant anthracycline-based therapy has been seen in patients with high infiltration of the tumour by CD8+ lymphocytes [3]. It has been suggested that interferon (IFN)$\gamma$-producing CD8 $\mathrm{T}$ lymphocytes play a role in local primary immunity against tumours $[4,5]$.

Neoadjuvant chemotherapy (NACT) can stimulate antitumour immunity, thereby increasing the pathological complete response (pCR) to the treatment [6]. Indeed, in the neoadjuvant setting, studies have highlighted the importance of assessing tumour-infiltrating lymphocytes (TILs) for predicting pCR, and this is strongly associated with a better prognosis in triple-negative breast cancer (TNBC) and HER2-positive breast cancer [7]. Many known predictive factors of NACT response are related to the phenotypic character of tumour cells (review [8]). The role of the tumour microenvironment in the neoadjuvant setting is now emerging. This review aims to summarise the current knowledge about immune cells infiltrating the tumour microenvironment in breast carcino$\mathrm{ma}$, in an effort to shed light on their predictive and prognostic role and the implications for the response to neoadjuvant chemotherapy. The various cellular components of the immune microenvironments, the methods of assessing them, and their relevance in the neoadjuvant setting are discussed below.

\section{Evaluation of Immune Cells in the Tumour Microenvironment of Breast Cancer}

Immune cells constitute an important component of the tumour microenvironment and are found either in the stroma surrounding the tumour nests (stromal) or are in direct contact with the tumour cells (intratumoural).

Several methods have been developed to evaluate immune cell infiltration, particularly that of the lymphocytic infiltrate. Hematoxylin and eosin (H\&E)-stained slides of tumour tissue are used to assess the percentage of infiltrating lymphocytes. The International Immuno-Oncology Biomarker Working Group on Breast Cancer recommended the use of microscopic magnification of $\times 200$ 400 (ocular $\times 10$, with an objective of $\times 20-40$ ) of H\&Estained FFPE tissue sections $(4-5 \mu \mathrm{m})$ to assess TILs. All mononuclear cells including lymphocytes and plasma cells should be scored. Polymorphonuclear leukocytes and other granulocytes (i.e., eosinophils and basophils) are excluded. Quantitative assessment of other mononuclear cells such as dendritic cells and macrophages is currently not recommended, although there is increasing evidence that they may be functionally important. The Working Group recommended the evaluation of stromal TILs that are not in direct contact with invasive carcinoma cells rather than the intratumoural TILs in the tumour nests, because the stromal compartment is not affected by the density and growth pattern of the nests (Fig. 1a). Only TILs within the borders of the invasive tumours are evaluated (with the invasive edge being included in the evaluation but not reported separately). Immune infiltrates outside of the tumour borders, e.g., in the adjacent normal tissue or a ductal carcinoma in situ (DCIS) should not be included in the assessment [9]. Areas with crush artefacts, necrosis, and inflammation around biopsy sites, or extensive central regressive hyalinization should be ignored. Various cut-off values to define positivity are used. A phenotype of breast tumours with a particularly high lymphocytic infiltration, constituting $>50-60 \%$ of the tumour microenvironment is classified as lymphocyte-predominant breast carcinoma (LPBC) [6, 10-12].

The assessment of TILs in residual disease following NACT remains a challenge. While the recommendations
62

Pathobiology 2020;87:61-74 DOI: $10.1159 / 000504055$
Badr/Berditchevski/Shaaban 

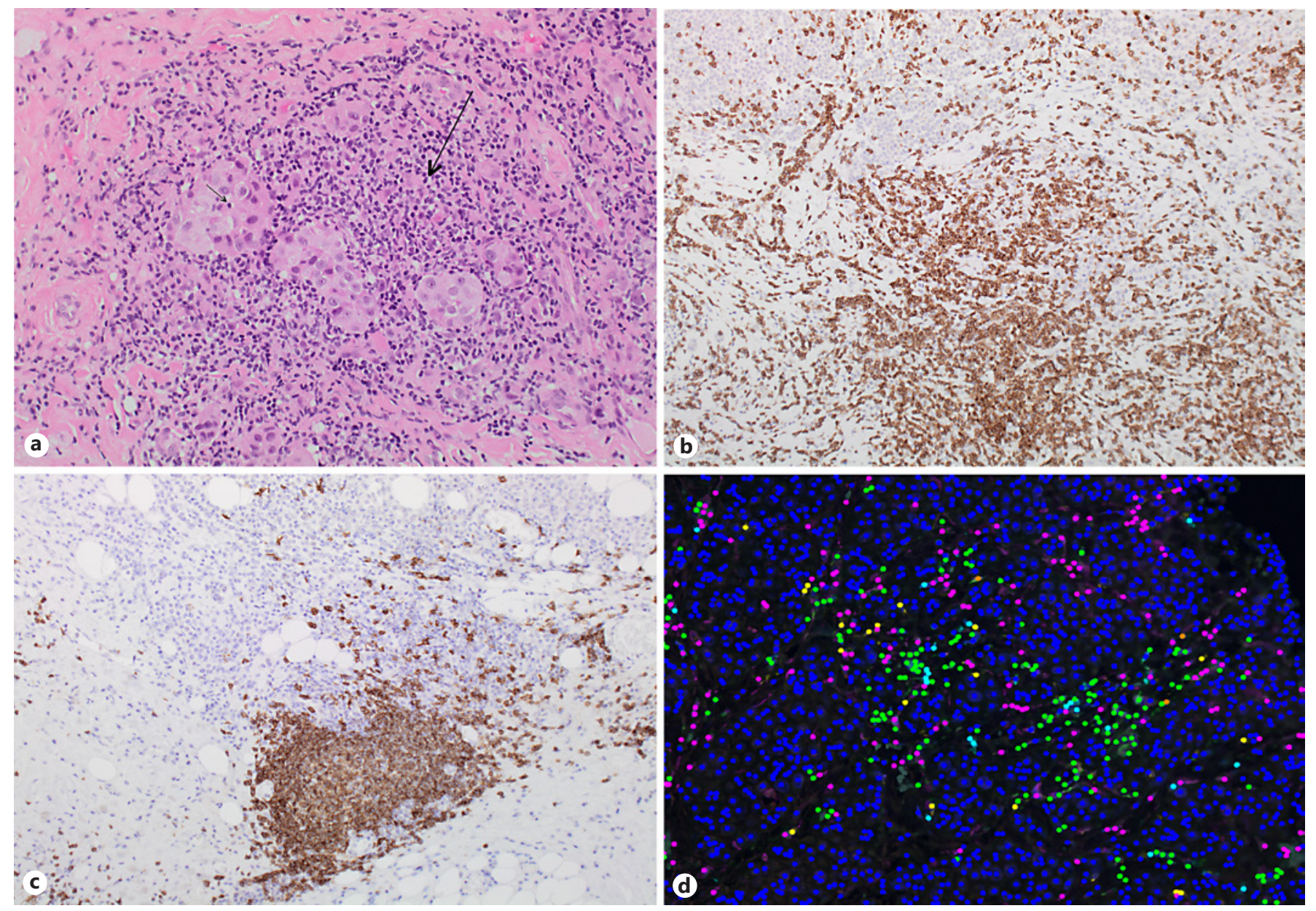

Fig. 1. Methods of assessment of the inflammatory microenvironment of invasive breast carcinoma. a Section of invasive breast carcinoma showing stromal (long arrow) and intratumoural (short arrow) tumour-infiltrating lymphocytes (TILs). H\&E. b Immunohistochemical staining of CD3+ T cells showing stromal and intratumoural TILs. c Immunohistochemical staining including a

CD20-positive lymphoid aggregate at the tumour-stromal interphase. $\mathbf{d}$ Example of multiplex immunofluorescence showing concomitant expression of various cellular components. Green, CD4+ TILs; yellow, CD8+ TILs; magenta, CD68+ TIMs; cyan, CD20+ TILs; orange, FOXP3+ TILs. Blue shows nuclear counterstaining (DAPI).

are similar to those for pretreated samples, it has been suggested that the area for assessment should be confined to the borders of the residual tumour bed, defined as the largest cross-sectional area between residual invasive tumour cells. Stromal TILs in residual disease are defined according to the percentage of stromal areas occupied by mononuclear inflammatory cells within the boundaries of the residual tumour bed [13]. Immunohistochemical staining has been used to differentiate the subtypes of immune cells (Fig. 1b, c). Authors have adapted different semiquantitative grading methods, i.e., from absent to high infiltration levels, according to the percentage of infiltrating lymphocytes by eyeballing $[14,15]$.

The Immune Microenvironment in Breast

Pathobiology 2020;87:61-74 
TILs and the Response to Different Chemotherapy Regimens

An increased number of TILs is associated with good outcomes for breast cancer patients after NACT. This was first demonstrated by Denkert et al. [6] in their analysis of 1,058 patients' core biopsies. A pCR rate of $40-42 \%$ of the patients was achieved with high TIL infiltration (>10\%) following neoadjuvant anthracycline-/taxane-based chemotherapy, whereas tumours with low infiltration achieved pCR in only $3-7 \%$ of patients. Similar findings were described in hormone receptor-negative, HER2-positive breast cancer patients treated with only anthracyclinebased NACT [19]. Issa-Nummer et al. [11] showed that increased infiltration by stromal lymphocytes, especially in LPBC, was an independent predictor for pCR in the multivariate analysis of a cohort of 313 breast cancer patients. Furthermore, the increased number of intratumoural lymphocytes was predictive for $\mathrm{PCR}$ in the univariate analysis. The authors did not comment on an association of TILs and patient survival as no survival analysis was performed in this study. In inflammatory breast carcinoma (IBC), stromal TIL infiltration of $>10 \%$ was considered a significant predictor of improved overall survival (OS) in patients who received neoadjuvant therapy with taxane [20].

\section{TILs and the Neoadjuvant Response in Breast Cancer Molecular Subtypes}

In one of the earlier studies, high TIL infiltration in TNBC was positively correlated with $\mathrm{pCR}$ after neoadjuvant anthracycline chemotherapy alone, taxane-based regimens alone, and anthracycline and taxane sequentially or concurrently [21]. Similarly, Oda et al. [22] showed an association between high inflitration and pCR in a group of TNBC patients treated with paclitaxel followed by a combination of fluorouracil, epirubicin, and cyclophosphamide (FEC).

TNBC subtyping can be a predictor of the pCR to neoadjuvant chemotherapy [23]. Six molecular subtypes, namely basal-like (BL)1, BL2, mesenchymal, mesenchymal stem-like, immunomodulatory, and luminal androgen receptor were identified [24]. They were subsequently reduced to 4 subtypes (BL1, BL2, mesenchymal, and luminal androgen receptor) [25]. The immunomodulatory gene expression signature was described as an indicator of the presence of TILs [25]. The BL1 subtype had both a high rate of the immunomodulatory positive signature $(48 \%)$ with a pCR rate of $52 \%$, while the BL2 (30\%) and luminal androgen receptor (18\%) subtypes had lower rates of the immunomodulatory positive signature as well as the lowest pCR rates (0 and 10\%, respectively) [24].
High TIL infiltration has been correlated to pCR in HER2-positive breast cancer following neoadjuvant anthracycline treatment [3]. A prospective study of 498 HER2-positive breast cancer samples of the neoadjuvant GeparQuattro (G4) and GeparQuinto trials (G5) showed that the LPBC phenotype was strongly associated with pCR in the whole cohort as well as in the G4 group. Additionally, patients who were treated with trastuzumab showed higher $\mathrm{pCR}$ rates than those treated with lapatinib-based therapy. The LPBC phenotype was significantly associated with pCR in the trastuzumab-treated subgroup. Although disease-free survival (DFS) was significantly associated with a high pCR rate in the whole cohort, no significant association was seen between LPBC and DFS. By combining both pCR and LPBC, 2 prognostic subgroups of patients were identified. Patients with pCR and LPBC were defined as a low-risk group with a long DFS and those with no pCR/ LPBC were considered a high-risk group with an increased rate of recurrence. In the whole cohort, the LPBC without pCR group represented $42.3 \%$ of patients and the non-LPBC with pCR group comprised $40.4 \%$. It has been proposed that this subgrouping may help identify patients who would benefit from the addition of new therapeutic strategies that target the immune response [26].

In the PROMIX phase 2 trial of 150 patients with locally advanced hormone receptor-positive/HER2-negative breast cancer, a low abundance of FOXP3+ TILs $(<10 \%)$ in cycle 2 correlated with an improved DFS following neoadjuvant docetaxel and epirubicin [27].

\section{TILs in the Post-NACT Residual Disease Setting}

Residual cancer burden (RCB) was developed as a method to quantify residual disease after NACT in breast carcinoma [28]. The RCB index depends on histopathological variables such as the number of nodes involved, the size of the largest nodal metastasis, and the size and percentage of cellularity of the primary tumour bed. It can be calculated through a web-based calculator, both as a numerical score and as a category [29]. RCB has been shown to have a useful predictive value for long-term survival after NACT $[28,30]$.

Heterogeneous immune response to NACT in the residual setting has been observed, with $48 \%$ of patients showing an increase in the level of TILs in residual disease and $47 \%$ experiencing a decrease [31]. The presence of $>60 \%$ TILs in residual disease after NACT was associated with a better prognosis in patients with TNBC [10]. A significant positive correlation was found between high TIL
Badr/Berditchevski/Shaaban 
infiltration in post-NACT residual breast tumours and both metastasis-free survival and OS, with a relative decrease in the risk of metastasis and death and increase of 5-year metastasis-free survival and OS rates [10].

TIL infiltration in TNBC residual tumours was found to be predictive of recurrence-free survival (RFS) and OS in a study on 111 patients who received neoadjuvant doxorubicin and cyclophosphamide (half of them also received paclitaxel). The residual tumours with a low level of TILs were enriched with activating genomic alterations in the RAS-MAPK pathway (amplifications in KRAS, BRAF, RAF1, and truncations in NF1), which cause the suppression of MHC-I/II expression. These results suggested that the activation of the RAS-MAPK pathway might represent a possible mechanism by which tumour cells bypass the antigen presentation processes, thereby reducing immune recognition and lymphocyte infiltration [32]. By contrast, the extent of lymphocyte infiltration into primary HER-positive tumours was not correlated with pCR and a high level of TILs in residual disease following neoadjuvant trastuzumab therapy was associated with a poor prognosis [33].

Asano et al. [34] developed an indicator termed RCBTILs by combining both RCB and TIL evaluations. They assessed its clinical application following neoadjuvant FEC100 and paclitaxel, with the addition of trastuzumab in the HER2-positive breast cancer group. Patients who were RCB class I and positive for TILs were considered RCB-TILs-positive, and all other combinations were RCB-TILs-negative. RCB-TILs-positive breast cancer was shown to be associated with longer survival and a lower rate of recurrence. In posttreated excisional samples, high TIL infiltration ( $>20 \%)$ correlated with a better RFS and OS in patients with RCB class II than in those with RCB class III [35].

\section{TIL Subsets and Neoadjuvant Response \\ CD3+ TILs}

In one of the earlier studies, the infiltration of $\mathrm{CD} 3+\mathrm{T}$ cells could predict the response to NACT in breast cancer (Table 1). This was shown in a cohort of 25 breast cancer patients treated with neoadjuvant paclitaxel therapy. High CD3+ TIL infiltration in the tumour bed correlated significantly with the response to therapy [14]. Similarly, a subgroup of ER-negative breast cancer patients with high CD3+ TIL infiltration showed a remarkably high (74\%) pCR rate to neoadjuvant anthracycline-based therapy. A high CD3+ TIL level was significantly associated with increased DFS, both HER2- and progesterone receptor (PR)-negative status and strongly associated with a

The Immune Microenvironment in Breast Carcinoma high tumour grade [3]. Increased levels of CD3+ TILs also predicted the $\mathrm{pCR}$ to a neoadjuvant anthracycline + taxane combination; their high infiltration was associated with an increased response rate [36].

\section{CD4+, CD8+, and FOXP3+ TILs}

High CD4+, CD8+, and FOXP3+ TIL infiltration was correlated with $\mathrm{pCR}$ in TNBC patients treated with neoadjuvant anthracycline-/anthracycline + taxanebased therapy [37]. High infiltration of both FOXP3+ and CD8+ TILs in pretreated biopsies featured high pCR rates in patients who received neoadjuvant paclitaxel followed by FEC [22]. A high CD8/FOXP3+ TIL ratio in pretreatment biopsies was significantly associated with pCR in TNBC and HER2-positive breast cancer, following FEC100 and paclitaxel + trastuzumab in HER2-positive breast cancer patients. Following NACT, TIL evaluation revealed a decreased CD8/FOXP3+ TIL ratio in recurrent TNBC and HER2-positive breast cancer but remained unchanged in hormone responsive breast cancer, possibly reflecting an association between tumour recurrence and a reduction in tumour immunity in the cancer microenvironment [38]. A high level of CD8+ TILs and a high CD8/FOXP3+ TIL ratio in a residual tumour could predict an improvement in RFS and breast cancer-specific survival (BCSS) in TNBC patients with non-pCR following neoadjuvant anthracycline + taxane chemotherapy [39]. Recently, Goto et al. [40] noticed an increased CD8/FOXP3+ TIL ratio following treatment with FEC100 followed by paclitaxel. This increase was significantly associated with improved clinical outcomes in TNBC and hormone-responsive breast cancer.

CD20+TIL and PDL-1 Expression in Breast Cancer

Only a few studies have examined the prognostic value of tumour-infiltrating B cells (CD20+ TILs) in breast cancer patients receiving NACT. Denkert et al. [6] found a significant correlation between the CD20+ TIL and pCR. A highly responsive group of breast carcinoma patients was characterized by higher CD20+ TIL infiltration in their pretreatment biopsies, with a statistically significant decrease of CD20+ cell counts after anthracycline-/anthracycline + taxane-based therapy only, and with the addition of trastuzumab to HER2-positive breast cancer patients [41]. In a study of pretreatment 580 breast cancer biopsies, high CD20 expression was associated with a 5.5 times likelihood of a pCR to a neoadjuvant anthracycline + taxane combination [36]. Coexistence of CD20+ TILs and PD$\mathrm{L} 1+$ tumour cells were significantly associated with better 
Table 1. Summary of studies investigating the relationship between various types of immune cells and response to neoadjuvant chemotherapy

\begin{tabular}{|c|c|c|c|c|c|c|c|}
\hline $\begin{array}{l}\text { First author } \\
\text { [Ref.], year }\end{array}$ & $N$ & $\begin{array}{l}\text { Molecular } \\
\text { phenotype }\end{array}$ & Time point & Assay & Marker & Scoring/cutoff & Correlation \\
\hline $\begin{array}{l}\text { Demaria } \\
{[14], 2001}\end{array}$ & 25 & all & $\begin{array}{l}\text { pre- and } \\
\text { post-NACT }\end{array}$ & $\begin{array}{l}\text { H\&E } \\
\text { IHC }\end{array}$ & $\begin{array}{l}\text { CD8 } \\
\text { CD3 }\end{array}$ & score $>0$ & positive correlation with $\mathrm{pCR}$ \\
\hline $\begin{array}{l}\text { Ladoire } \\
{[15], 2008}\end{array}$ & 56 & all & pre-NACT & IHC & $\begin{array}{l}\text { CD3 } \\
\text { CD8 } \\
\text { FOXP3 }\end{array}$ & score $>0$ & $\begin{array}{l}\text { high CD8+ TILs positively correlated } \\
\text { with pCR }\end{array}$ \\
\hline $\begin{array}{l}\text { Denkert } \\
{[6], 2010}\end{array}$ & 1,058 & all & pre-NACT & $\mathrm{H} \& \mathrm{E}$ & TILs & $60 \%$ & positive correlation with $\mathrm{pCR}$ \\
\hline $\begin{array}{l}\text { Ono } \\
{[21], 2012}\end{array}$ & 180 & TNBC & post-NACT & $\mathrm{H} \& \mathrm{E}$ & TILs & score $>0$ & positive correlation with $\mathrm{pCR}$ \\
\hline $\begin{array}{l}\text { Yamaguchi } \\
{[19], 2012}\end{array}$ & 68 & $\begin{array}{l}\text { HER2-positive/ } \\
\text { HER2-negative } \\
\text { BC }\end{array}$ & pre-NACT & $\mathrm{H} \& \mathrm{E}$ & TILs & score $>0$ & positive correlation with $\mathrm{pCR}$ \\
\hline $\begin{array}{l}\text { Oda } \\
{[22], 2012}\end{array}$ & 180 & all & $\begin{array}{l}\text { pre- and } \\
\text { post-NACT }\end{array}$ & IHC & $\begin{array}{l}\text { FOXP3 } \\
\text { CD8 }\end{array}$ & median value & $\begin{array}{l}\text { positive correlation with } \mathrm{pCR} \text { before NACT } \\
\text { negative correlation with } \mathrm{pCR} \text { after NACT }\end{array}$ \\
\hline $\begin{array}{l}\text { Issa-Nummer } \\
{[11], 2013}\end{array}$ & 313 & $\begin{array}{l}\text { TNBC } \\
\text { luminal }\end{array}$ & pre-NACT & $\mathrm{H} \& \mathrm{E}$ & TILs & $60 \%$ & positive correlation with $\mathrm{pCR}$ \\
\hline $\begin{array}{l}\text { Lee } \\
{[81], 2013}\end{array}$ & 175 & all & pre-NACT & IHC & $\begin{array}{l}\text { CD3 } \\
\text { CD8 } \\
\text { FOXP3 }\end{array}$ & $\begin{array}{l}10 \% \text { in } 10 \\
\text { increments }\end{array}$ & positive correlation with $\mathrm{pCR}$ \\
\hline $\begin{array}{l}\text { García-Martínez } \\
\text { [41], } 2014\end{array}$ & 121 & all & pre-NACT & IHC & $\begin{array}{l}\text { CD3 } \\
\text { CD8 } \\
\text { CD4 } \\
\text { CD20 } \\
\text { CD68 } \\
\text { FOXP3 }\end{array}$ & median value & $\begin{array}{l}\text { high CD4+ TILs positively correlated } \\
\text { with pCR } \\
\text { high infiltration of CD3+ TILs and } \\
\text { CD68+ cells negatively correlated } \\
\text { with DFS }\end{array}$ \\
\hline $\begin{array}{l}\text { Brown } \\
{[36], 2014}\end{array}$ & & all & pre-NACT & $\begin{array}{l}\text { H\&E } \\
\text { IHF }\end{array}$ & $\begin{array}{l}\text { CD3 } \\
\text { CD8 } \\
\text { CD20 }\end{array}$ & $\begin{array}{l}\text { determined by Join- } \\
\text { point software }\end{array}$ & positive correlation with $\mathrm{pCR}$ \\
\hline $\begin{array}{l}\text { Miyashita } \\
{[82], 2014}\end{array}$ & 110 & TNBC & pre-NACT & IHC & $\begin{array}{l}\text { CD8 } \\
\text { FOXP3 }\end{array}$ & median value & $\begin{array}{l}\text { high CD8+/FOXP3+ TILs ratios have a positive } \\
\text { correlation with } \mathrm{pCR}\end{array}$ \\
\hline $\begin{array}{l}\text { Bianchini } \\
{[83], 2015}\end{array}$ & 243 & $\begin{array}{l}\text { HER2-positive } \\
\text { LABC }\end{array}$ & pre-NACT & $\begin{array}{l}\text { TILs } \\
\text { IHC }\end{array}$ & PDL-1 & $\begin{array}{l}\text { TILs: } 50 \% \\
\text { PDL-1: score }>0\end{array}$ & no correlation with pCR \\
\hline $\begin{array}{l}\text { Miyashita } \\
{[39], 2015}\end{array}$ & 101 & TNBC & $\begin{array}{l}\text { pre- and } \\
\text { post-NACT }\end{array}$ & IHC & $\begin{array}{l}\text { CD8 } \\
\text { FOXP3 }\end{array}$ & $\begin{array}{l}\text { near the median } \\
\text { value }\end{array}$ & $\begin{array}{l}\text { high CD8+ TIL and CD8/FOXP } 3 \text { ratios } \\
\text { in residual tumors correlated with } \\
\text { improved RFS and BCSS }\end{array}$ \\
\hline $\begin{array}{l}\text { Denkert } \\
{[12], 2015}\end{array}$ & 580 & $\begin{array}{l}\text { HER2-positive } \\
\text { TNBC }\end{array}$ & pre-NACT & $\mathrm{H} \& \mathrm{E}$ & TILs & $60 \%$ & positive correlation with $\mathrm{pCR}$ \\
\hline
\end{tabular}


Table 1 (continued)

\begin{tabular}{|c|c|c|c|c|c|c|c|}
\hline $\begin{array}{l}\text { First author } \\
\text { [Ref.], year }\end{array}$ & $N$ & $\begin{array}{l}\text { Molecular } \\
\text { phenotype }\end{array}$ & Time point & Assay & Marker & Scoring/cutoff & Correlation \\
\hline $\begin{array}{l}\text { Ali } \\
{[84], 2016}\end{array}$ & 768 & $\begin{array}{l}\text { HER2-positive } \\
\text { BC }\end{array}$ & pre-NACT & $\mathrm{H} \& \mathrm{E}$ & TILs & $\begin{array}{l}\text { scores } 0 \text { and } 1 \\
\text { according to TIL } \\
\text { abundancy }\end{array}$ & $\begin{array}{l}\text { positive correlation with relative } \\
\text { resistance to chemotherapy }\end{array}$ \\
\hline $\begin{array}{l}\text { Asano } \\
{[38], 2016}\end{array}$ & 177 & all & pre-NACT & $\begin{array}{l}\mathrm{H} \& \mathrm{E} \\
\mathrm{IHC}\end{array}$ & $\begin{array}{l}\text { CD8 } \\
\text { FOXP3 }\end{array}$ & $\begin{array}{l}\text { mean numbers/ } \\
\text { per field }\end{array}$ & $\begin{array}{l}\text { high } \mathrm{CD} 8+/ \mathrm{FOXP} 3+\text { TILs ratio positively } \\
\text { correlated with } \mathrm{pCR} \text { in TNBC and } \\
\text { HER2-positive BC }\end{array}$ \\
\hline $\begin{array}{l}\text { Ingold } \\
{[26], 2016}\end{array}$ & 498 & $\begin{array}{l}\text { HER2-positive } \\
\text { BC }\end{array}$ & post-NACT & $\mathrm{H} \& \mathrm{E}$ & TILs & $60 \%$ & positive correlation with $\mathrm{pCR}$ \\
\hline $\begin{array}{l}\text { Asano } \\
{[34], 2017}\end{array}$ & & all & pre-NACT & $\mathrm{H} \& \mathrm{E}$ & TILs & score $>10 \%$ & $\begin{array}{l}\text { RCB-TILs is a significant predictor for } \\
\text { BC recurrence after NACT }\end{array}$ \\
\hline $\begin{array}{l}\text { Ibrahiem } \\
\text { [85], } 2017\end{array}$ & 100 & all & pre-NACT & $\mathrm{IHC}$ & $\begin{array}{l}\text { CD3 } \\
\text { CD20 } \\
\text { CD4 } \\
\text { CD8 }\end{array}$ & $50 \%$ & positive correlation of CD8+ TILs \\
\hline $\begin{array}{l}\text { Al-Saleh } \\
{[86], 2017}\end{array}$ & 31 & $\begin{array}{l}\text { luminal B/ } \\
\text { HER2-negative }\end{array}$ & pre-NACT & $\mathrm{IHC}$ & CD8 & median value & positive correlation with $\mathrm{pCR}$ and OS \\
\hline $\begin{array}{l}\text { Mitrofanova } \\
{[56], 2017}\end{array}$ & 50 & all & pre-NACT & $\mathrm{IHC}$ & $\begin{array}{l}\text { CD68 } \\
\text { Stabillin-1 }\end{array}$ & $\begin{array}{l}\text { digital pathology } \\
\text { (Aperio Image } \\
\text { Scope) }\end{array}$ & negative correlation with high CD68+ cells \\
\hline $\begin{array}{l}\text { Kaewkangsadan } \\
\text { [57], } 2017\end{array}$ & 33 & all & pre-NACT & $\mathrm{IHC}$ & $\begin{array}{l}\text { CD68 } \\
\text { CD163 } \\
\text { CD1a } \\
\text { CD66b }\end{array}$ & score $>0$ & $\begin{array}{l}\text { high CD163+ TIM infiltration positively } \\
\text { correlated with pCR }\end{array}$ \\
\hline $\begin{array}{l}\text { Siregar } \\
{[87], 2017}\end{array}$ & 51 & all & post-NACT & $\mathrm{H} \& \mathrm{E}$ & TILs & $50 \%$ & no correlation with pCR \\
\hline $\begin{array}{l}\text { Hamy } \\
{[33], 2017}\end{array}$ & 175 & $\begin{array}{l}\text { HER2-positive } \\
\text { BC }\end{array}$ & $\begin{array}{l}\text { pre- and } \\
\text { post-NACT }\end{array}$ & $\mathrm{H} \& \mathrm{E}$ & TILs & $\begin{array}{l}\text { the value that yields } \\
\text { the lowest } p \text { value } \\
\text { concerning the } \\
\text { association with DFS }\end{array}$ & $\begin{array}{l}\text { no correlation with pCR in post-treated } \\
\text { cases }\end{array}$ \\
\hline $\begin{array}{l}\text { Pelekanou } \\
{[88], 2017}\end{array}$ & 58 & all & $\begin{array}{l}\text { pre- and } \\
\text { post-NACT }\end{array}$ & $\begin{array}{l}\mathrm{H} \& \mathrm{E} \\
\mathrm{IHF}\end{array}$ & $\begin{array}{l}\text { TILs } \\
\text { PDL-1 }\end{array}$ & $\begin{array}{l}1 \% \\
\text { (AQUA, digital } \\
\text { pathology) }\end{array}$ & $\begin{array}{l}\text { positive correlation with recurrence-free } \\
\text { survival in residual tumour }\end{array}$ \\
\hline $\begin{array}{l}\text { Cha } \\
{[89], 2018}\end{array}$ & 220 & all & $\begin{array}{l}\text { pre- and } \\
\text { post-NACT }\end{array}$ & $\mathrm{H} \& \mathrm{E}$ & TILs & $60 \%$ & $\begin{array}{l}>5 \text { cores may accurately predict the TIL } \\
\text { score of the entire tumour }\end{array}$ \\
\hline $\begin{array}{l}\text { Hou } \\
{[43], 2018}\end{array}$ & 123 & $\begin{array}{l}\text { HER2-positive } \\
\text { BC }\end{array}$ & pre-NACT & $\mathrm{IHC}$ & $\begin{array}{l}\text { PDL-1 } \\
\text { CD163 } \\
\text { CD8 }\end{array}$ & $\begin{array}{l}\text { PDL- } 1 \text { : } \\
\text { score } \geq 1 \% \text { of } \\
\text { tumour cells. } \\
\text { CD8 and CD } 163 \text { : } \\
\text { score }>1 \%\end{array}$ & $\begin{array}{l}\text { high CD8+ cells and PD-L1 expression could } \\
\text { predict response to anti-HER } 2 \\
\text { targeted therapy }\end{array}$ \\
\hline $\begin{array}{l}\text { Arias-Pulido } \\
{[42], 2018}\end{array}$ & 221 & all & pre-NACT & $\begin{array}{l}\mathrm{H} \& \mathrm{E} \\
\mathrm{IHC}\end{array}$ & $\begin{array}{l}\text { CD20 } \\
\text { PDL-1 }\end{array}$ & $\begin{array}{l}\text { PDL- } 1: \\
\text { score } \geq 5 \% \\
\text { CD } 20: \\
\text { score } \geq 1 \%\end{array}$ & $\begin{array}{l}\text { high CD20+ TILs positively correlated } \\
\text { with pCR and survival } \\
\text { coexistence of CD20+ and PD-L1+ TILs } \\
\text { positively correlated with better outcome }\end{array}$ \\
\hline $\begin{array}{l}\text { Asano } \\
{[90], 2018}\end{array}$ & 177 & all & pre-NACT & $\mathrm{H} \& \mathrm{E}$ & TILs & score $>0$ & $\begin{array}{l}\text { positive correlation with pCR in TNBC } \\
\text { and HER2-positive BC }\end{array}$ \\
\hline $\begin{array}{l}\text { Elsayed } \\
{[91], 2018}\end{array}$ & 45 & all & pre-NACT & $\mathrm{IHC}$ & $\mathrm{CD} 8$ & $50 \%$ & $\begin{array}{l}\text { high CD8+ TILs positively correlated } \\
\text { with DFS but not with pCR }\end{array}$ \\
\hline $\begin{array}{l}\text { Goto } \\
{[40], 2018}\end{array}$ & 136 & all & $\begin{array}{l}\text { pre- and } \\
\text { post-NACT }\end{array}$ & $\begin{array}{l}\mathrm{H} \& \mathrm{E} \\
\mathrm{IHC}\end{array}$ & $\begin{array}{l}\text { TILs } \\
\text { CD8 } \\
\text { FOXP3 }\end{array}$ & $\begin{array}{l}\text { TILs: } \\
\text { score }>10 \%\end{array}$ & $\begin{array}{l}\text { positive correlation of high CD } 8+/ F O X P 3+ \\
\text { TILs ratio in TNBC and hormone-responsive } \\
\text { BC }\end{array}$ \\
\hline
\end{tabular}


Table 1 (continued)

\begin{tabular}{|c|c|c|c|c|c|c|c|}
\hline $\begin{array}{l}\text { First author } \\
\text { [Ref.], year }\end{array}$ & $N$ & $\begin{array}{l}\text { Molecular } \\
\text { phenotype }\end{array}$ & Time point & Assay & Marker & Scoring/cutoff & Correlation \\
\hline $\begin{array}{l}\text { Luen } \\
\text { [35], } 2019\end{array}$ & 375 & TNBC & $\begin{array}{l}\text { pre- and } \\
\text { post-NACT }\end{array}$ & IHC & $\begin{array}{l}\text { CD8 } \\
\text { FOXP3 }\end{array}$ & $20 \%$ & $\begin{array}{l}\text { positive correlation with patient survival } \\
\text { in residual disease }\end{array}$ \\
\hline $\begin{array}{l}\text { Eryilmaz } \\
\text { [92], } 2018\end{array}$ & 62 & all in (LABC) & $\begin{array}{l}\text { pre- and } \\
\text { post-NACT }\end{array}$ & $\mathrm{H} \& \mathrm{E}$ & TILs & $\begin{array}{l}\text { mean number of } \\
\text { positive cells } / \mathrm{mm}^{2} \\
\text { of tissue }\end{array}$ & positive correlation with $\mathrm{pCR}$ \\
\hline $\begin{array}{l}\text { Denkert } \\
{[93], 2018}\end{array}$ & 3,771 & all & pre-NACT & $\mathrm{H} \& \mathrm{E}$ & TILs & score $>0$ & $\begin{array}{l}\text { positive correlation with pCR and survival } \\
\text { in TNBC and HER2-positive BC }\end{array}$ \\
\hline $\begin{array}{l}\text { Ruan } \\
{[94], 2018}\end{array}$ & 166 & TNBC & pre-NACT & $\mathrm{H} \& \mathrm{E}$ & TILs & $\begin{array}{l}\text { score }>5 \% \text { in } 10 \\
\text { increments }\end{array}$ & positive correlation with $\mathrm{pCR}$ \\
\hline $\begin{array}{l}\text { Miyoshi } \\
\text { [95], } 2019\end{array}$ & 639 & all & pre-NACT & $\mathrm{H} \& \mathrm{E}$ & TILs & $\begin{array}{l}\text { cutoff points for TIL } \\
\text { proportions }(10,30 \text {, } \\
\text { and } 50 \%)\end{array}$ & $\begin{array}{l}\text { positive correlation with aggressive } \\
\text { phenotypes of BC and NACT response }\end{array}$ \\
\hline $\begin{array}{l}\text { de Groot } \\
{[96], 2019}\end{array}$ & 196 & all & pre-NACT & IHC & $\begin{array}{l}\text { CD8 } \\
\text { FOXP3 } \\
\text { CD68 } \\
\text { HLA class } 1\end{array}$ & median value & $\begin{array}{l}\text { high CD8+ TILs in the presence of } \\
\text { tumoral HLA class } 1 \text { expression } \\
\text { positively correlated with pCR and } \\
\text { DFS in HER2-negative BC }\end{array}$ \\
\hline $\begin{array}{l}\text { Kurozumi } \\
{[97], 2019}\end{array}$ & 128 & $\begin{array}{l}\text { HER2-positive } \\
\text { BC }\end{array}$ & post-NACT & $\mathrm{H} \& \mathrm{E}$ & TILs & score $>0$ & $\begin{array}{l}\text { positive correlation with better prognosis } \\
\text { in residual tumours }\end{array}$ \\
\hline $\begin{array}{l}\text { Van Berckelaer } \\
{[20], 2019}\end{array}$ & 143 & IBC & pre-NACT & IHC & PDL-1 & $\begin{array}{l}\text { TILs: } \\
\text { score }>10 \% \\
\text { PDL- } 1: \\
\text { score }>0\end{array}$ & $\begin{array}{l}\text { PD-L1-expression is a characteristic of } \\
\text { the IBC microenvironment }\end{array}$ \\
\hline
\end{tabular}

BC, Breast cancer; TNBC, triple-negative breast carcinoma; DFS, disease-free survival; RCB, residual cancer burden; TIMs, tumour-infiltrating macrophages; IHF, immunofluorescence; LABC, locally advanced breast carcinoma; IBC, inflammatory breast carcinoma; TI-NK, tumour-infiltrating natural killer cells; HPF, high power field; BCSS, breast cancer-specific survival; RFS, recurrence-free survival; H\&E, haematoxylin and eosin.

survival,a high pCR rate, and high infiltration of TILs in triple-negative IBC. High CD20+ and PD-L1+ TIL infiltration correlated with fewer relapses, a high pCR, and higher rates of DFS and BCSS [42]. PD-L1 expression in tumour cells was positively associated with a high infiltration of intratumoural/peritumoural CD8+ TILs and CD163+ macrophages in HER2-positive breast cancer [43].

\section{Natural Killer Cells}

Natural killer (NK) cells contribute to tumour surveillance, the inhibition of tumour growth, and the defence against metastatic processes [44]. Their role in breast cancer and a correlation with pCR following chemotherapeutic treatment remain poorly documented in the literature. Verma et al. [44] observed a significant reduction in cytotoxicity mediated by circulating NK cells in tumours with a poor NACT response. Conversely, there was a significant increase in NK cells in the peritumoural environment in tumours that achieved a good pathological response. However, intratumoural NK cells did not show the same correlation. Increased activity of NK cells in the peripheral blood following neoadjuvant therapy correlated with the disappearance of lymph node metastasis in breast cancer patients [45]. A significant increase in the number of activated NK cells in the peripheral blood was observed in HER2-positive breast cancer in 
patients with pCR [46]. The expression of $6 \mathrm{NK}$-specific genes (NCR3 (NKp30), NCR1 (NKp46), CD96, CRTAM, $D N A M 1$, and $N K G 2 D)$ was predictive of an improved outcome in patients with breast cancer [47]. In another study, the upregulation of selected effector molecules related to an NK cell-mediated cytotoxicity pathway (GZMB, PRF1, NCR1, KIRs, and KLRCs) correlated with better OS and DFS in breast cancer patients [48]. A notable association was described between the increase in the number of tumour-infiltrating NK cells (TI-NKs) in pretreated biopsies and the pCR to anti-HER2 antibodybased neoadjuvant treatment combined with standard neoadjuvant chemotherapy in HER2-positive breast cancer. The tumours showing infiltration by $\geq 3$ TI$\mathrm{NKs} / 50 \times \mathrm{HPF}$ were associated with a higher $\mathrm{pCR}$ rate and the presence of $\geq 1 \mathrm{TI}-\mathrm{NKs} / 50 \times \mathrm{HPF}$ correlated with improved DFS [49].

\section{Tumour-Infiltrating Macrophages}

Activated M1 macrophages release proinflammatory cytokines and toxic intermediates and stimulate a cytotoxic effect on tumour cells through the activation of a type I T cell response [50]. However, tumour-infiltrating macrophages (TIMs) have been shown to impart a poor prognostic outcome in breast carcinoma. A decreased relapse-free survival and OS in breast cancer were found to be associated with the infiltration of CD68+ macrophages [51]. This was explained by the growth- and invasion-promoting effects of M2 macrophages on tumour cells via the release of proteolytic enzymes, their immunosuppressive activity, and their contribution to hypoxia-induced angiogenesis [52]. M2 macrophages have also been recognized as key players in the metastatic progression of breast cancer [53]. Only a few studies have assessed the prognostic value of the different locations of TIMs as an effector on their functions. Elevated stromal macrophages were positively correlated with large-sized and high-grade tumours and a poor OS and BCSS and were inversely correlated with luminal A breast cancer [54]. Other studies show that an aggressive outcome is associated with a high infiltration of TIMs irrespective of histological location [55].

\section{TIMs and Response to Neoadjuvant Chemotherapy}

High CD68+ TIM infiltration has been associated with worse DFS and OS in breast cancer patients following neoadjuvant taxane and anthracycline (+ trastuzumab) administration to patients with HER2 overexpression [41]. CD68+ TIMs located within parenchymal tissues

The Immune Microenvironment in Breast Carcinoma correlated negatively with lymphatic metastasis following neoadjuvant cyclophosphamide methotrexate fluorouracil (CMF) or fluorouracil, adriamycin, and cytoxan (FAC) [56]. A trial involving 108 breast cancer patients evaluated the effect of the addition of capecitabine to docetaxel preceded by adriamycin and cyclophosphamide in a neoadjuvant setting [57]. It reported that only CD163+ TIMs (a M2 macrophage phenotype) correlated with pCR. Although this finding was unexpected, the authors attributed it to a possible suppressive effect on the tumour caused by the interaction of parenchymal macrophages with tumour cells following therapy. Baseline abundance of CD163+ macrophages had neither a predictive nor a prognostic role in the PROMIX phase 2 trial that included 150 patients with locally advanced HER2-negative breast cancer treated with neoadjuvant epirubicin and docetaxel (+ bevacizumab) [27].

\section{Tumour-Infiltrating Neutrophils}

Polymorphonuclear leukocytes (neutrophils) constitute $50-60 \%$ of the total circulating leukocytes in the human body; they are considered the first line of defence against different types of microbes and also target tumour cells [58]. Tumour-infiltrating neutrophils (TINs) can stimulate tumour growth by releasing growth factors. These, together with the growth factors secreted by the tumour itself, may elicit a wound-healing-like response that, in turn, promotes tumour progression [59]. TINs can also facilitate tumour progression by stimulating angiogenesis and vascular invasion [60]. Increased levels of blood neutrophils have been described in various tumours including breast cancer [61]. A high neutrophilto-lymphocyte ratio in blood samples was associated with a poor outcome in breast cancer $[62,63]$.

\section{TINs and Response to Neoadjuvant Chemotherapy}

It was reported that, in patients with locally advanced breast cancer, pre-NACT high levels of circulating neutrophils were significantly associated with pCR in metastatic axillary lymph nodes following 8 cycles of capecitabine, docetaxel, adriamycin, and cyclophosphamide neoadjuvant regimens [57]. The decrease in circulating neutrophils following chemotherapy may be a reflection of drug toxicity and bone marrow suppression or a higher degree of overall cytotoxicity, including tumour-cell toxicity, and can lead to neutropenia. Therefore, the observed association with a pCR may have been in parallel and not necessarily causal. In the same study, CD66b+ 
neutrophils infiltrating breast tissue were few in number in the tumour microenvironment and showed no correlation with pathological response [57].

\section{Tumour-Infiltrating Dendritic Cells}

Dendritic cells are antigen-presenting cells that can initiate and direct variable adaptive immune responses [64]. Their deficient function may lead to an ineffective antitumour immune response in cancer [65]. Their capacity to present antigens may depend on their maturity, location, and likely also the regional differences around and within breast cancer $[66,67]$. Very few studies have investigated the prognostic role of tumour-infiltrating dendritic cells (TIDCs) in breast carcinoma patients. CD1a+ TIDCs have been found within breast tumours but with no statistical correlation between their density and tumour grade $[66,68]$. S100+ TIDC infiltration correlated positively with tumour grade, with a higher density in grade III tumours followed by grade II tumours; the lowest level of TIDCs were noted in grade I tumours $[66,69]$. CD83+ mature TIDCs were strongly associated with better patient survival in node-positive tumours compared to TIDCs expressing either S100 or CD1a (which showed no significant association with the prognostic parameters), indicating that TIDCs exhibit various phenotypes and functions in breast cancers depending on their level of maturation [70]. CD11c+ dendritic cells were significantly correlated with a high CD4+ CD8+ TILs count in surgical specimens of patients with TNBC. A positive correlation was also found between CD11c positivity and the formation of tertiary lymphocytic structures. Patients with moderate or abundant tertiary lymphoid structures had better survival than those with few or no tertiary lymphoid structures at more advanced pathological stages. Greater CD11c expression was associated with a better OS in TNBC patients with positive lymph node metastasis [71].

\section{TIDCs and Response to Neoadjuvant Chemotherapy}

A significant elevation in the level of dendritic cells in the blood was noted in breast cancer patients whose tumours showed a good pathological response following neoadjuvant capecitabine and docetaxel preceded by adriamycin and cyclophosphamide regimens. However, a significant reduction in the level of intratumoural CD1a+ TIDCs was reported, with no significant association with response to therapy, in both primary breast tumours and metastatic axillary lymph nodes [57].

\section{Conclusions and Future Directions}

The profile of immune cell subpopulations in the breast carcinoma microenvironment can identify a group of patients with tumours that are more responsive to various regimens of neoadjuvant chemotherapy. TILs, specifically, are important for predicting the neoadjuvant chemotherapy efficacy pre-, post-, or during treatment settings, mainly in TNBC. Recently, the international TILs Working Group, renamed the "International Immuno-Oncology Biomarker Working Group on Breast Cancer" developed an integrated survival prediction model for patients with early-stage TNBC, based on standard clinicopathological factors and stromal TILs. They developed an application which was designed to facilitate the use of this model [72]. An emerging role of TILs in DCIS has been described in recent studies. High TIL infiltration in DCIS correlates with adverse histopathological features [73-75]. Dense lymphocytes that touch the DCIS basement membrane or are located within a distance of 1-lymphocyte-cell-thickness from the basement membrane have been shown to be an independent prognostic factor for DCIS recurrence in patients treated with breast-conserving surgery regardless of other known determinants of tumour behaviour [76]. Recently, a $20 \%$ rate of TIL inflitration was described as the cutoff associated with the highest interobserver agreement [77].

Our study had several limitations. First, the sample size in the papers cited is highly variable. Second, there was variation across studies in the neoadjuvant chemotherapy regimens used. However, most of the studies showed significant correlation between TIL infiltration and pCR regardless of the type of therapy. Third, numerous methods with different cutoffs were used in the assessment of TILs. The recommended method remains the examination of H\&E-stained slides. And finally, there are only a limited number of studies investigating the role of TIMs, TINs, and TIDCs in breast carcinoma following NACT; clearly, more studies are needed to highlight their predictive role in the response to therapy. Further investigations into the subtypes and localisation of TILs in relation to the molecular phenotype of breast cancer are required to better understand the significance of the observed correlation and to develop algorithms that predict response. Quantitative digital analysis is likely to play an important role in this evolving field. Digital pathology can also be used to profile the immune cell infiltration in breast cancer and assess counts and densities with the aid of a variety of currently available software for image analysis such as UTHSCSA ImageTool [37], ImageJ [41], automated quantita- 
tive (AQUA) immunofluorescence multiplex analysis [36], and Aperio ImageScope [56]. Recently, we used Inform v2.2.1 software in the analysis of multiplex immunofluorescence stained breast cancer tissue to evaluate immune cell phenotypes in both the intratumoural and stromal areas of the tumour microenvironment in core biopsies of IBC following NACT [78] (Fig. 1d). The Working Group does not currently recommend machine-scoring approaches. The standardization of methodology and scoring in large series is required before large-scale digital scoring can be implemented. Recent promising results of the use of anti-PDL-1 immunotherapy in metastatic breast cancer have created an exciting new dimension for the management of breast cancer [79]. The study showed the significant survival advantage of adding anti-PDL-1 therapy to chemotherapy for metastatic TNBC. This paves the way for targeted therapies based not only on the molecular profile of the tumour epithelial cells but also on the composition and localisation of the components of the immune microenvironment.

\section{Disclosure Statement}

The authors have no conflicts of interest to declare.

\section{Funding Sources}

N.M.B. is sponsored by the Ministry of Higher Education and Scientific Research, General Mission Sector (Egypt) and the Queen Elizabeth Hospital Birmingham Charity. A.M.S. is supported by the Birmingham CR-UK Centre. F.B. is supported by the Inflammatory Breast Cancer Network UK.

\section{Author Contributions}

A.M.S. conceived the idea, reviewed the data, and contributed to writing it up. N.M.B. did the literature search, writing up, and produced the first draft. F.B. contributed to reviewing data and writing up. All authors approved the final manuscript.

\section{Search Strategy and Study Selection}

A literature search was performed on the PubMed and Google Scholar databases for studies that investigated the role of infiltrating immune cells in the microenvironment of breast carcinoma. The relevant studies that included data on tumour-infiltrating immune cells in the neoadjuvant setting were highlighted. The search strategy was limited to the English language and the deadline for the date of publication was June 2019. We included relevant literature reviews and the reference lists of the studies selected were also examined for additional eligible studies.

\section{References}

1 Dushyanthen S, Beavis PA, Savas P, Teo ZL, Zhou C, Mansour M, et al. Relevance of tumor-infiltrating lymphocytes in breast cancer. BMC Med. 2015 Aug;13(1):202.

2 Loi S, Sirtaine N, Piette F, Salgado R, Viale G, Van Eenoo F, et al. Prognostic and predictive value of tumor-infiltrating lymphocytes in a phase III randomized adjuvant breast cancer trial in node-positive breast cancer comparing the addition of docetaxel to doxorubicin with doxorubicin-based chemotherapy: BIG 02-98. J Clin Oncol. 2013 Mar;31(7):860-7.

3 West NR, Milne K, Truong PT, Macpherson $\mathrm{N}$, Nelson $\mathrm{BH}$, Watson PH. Tumor-infiltrating lymphocytes predict response to anthracycline-based chemotherapy in estrogen receptor-negative breast cancer. Breast Cancer Res. 2011;13(6):R126.

4 Lanitis E, Dangaj D, Irving M, Coukos G. Mechanisms regulating T-cell infiltration and activity in solid tumors. Ann Oncol. 2017 Dec;28:xii18-32.

5 Bhat P, Leggatt G, Waterhouse N, Frazer IH. Interferon- $\gamma$ derived from cytotoxic lymphocytes directly enhances their motility and cytotoxicity. Cell Death Dis. 2017 Jun; 8(6):e2836.

6 Denkert C, Loibl S, Noske A, Roller M, Müller BM, Komor M, et al. Tumor-associated lym- phocytes as an independent predictor of response to neoadjuvant chemotherapy in breast cancer. J Clin Oncol. 2010 Jan;28(1):105-13.

7 Salgado R, Loi S. Tumour infiltrating lymphocytes in breast cancer: increasing clinical relevance. Lancet Oncol. 2018 Jan;19(1):3-5.

8 Parekh T, Dodwell D, Sharma N, Shaaban AM. Radiological and Pathological Predictors of Response to Neoadjuvant Chemotherapy in Breast Cancer: A Brief Literature Review. Pathobiology. 2015 Sep;82(3-4):124-32.

9 https://www.tilsinbreastcancer.org: last accessed 12 August 2019.

10 Dieci MV, Criscitiello C, Goubar A, Viale G, Conte P, Guarneri V, et al. Prognostic value of tumor-infiltrating lymphocytes on residual disease after primary chemotherapy for triple-negative breast cancer: a retrospective multicenter study. Ann Oncol. 2014 Mar; 25(3):611-8.

11 Issa-Nummer Y, Darb-Esfahani S, Loibl S, Kunz G, Nekljudova V, Schrader I, et al. Prospective validation of immunological infiltrate for prediction of response to neoadjuvant chemotherapy in HER2-negative breast cancera substudy of the neoadjuvant GeparQuinto trial. PLoS One. 2013 Dec;8(12):e79775.

12 Denkert C, von Minckwitz G, Brase JC, Sinn BV, Gade S, Kronenwett R, et al. Tumor-infil- trating lymphocytes and response to neoadjuvant chemotherapy with or without carboplatin in human epidermal growth factor receptor 2-positive and triple-negative primary breast cancers. J Clin Oncol. 2015 Mar;33(9): 983-91.

13 Dieci MV, Radosevic-Robin N, Fineberg S, van den Eynden G, Ternes N, Penault-Llorca F, et al.; International Immuno-Oncology Biomarker Working Group on Breast Cancer. Update on tumor-infiltrating lymphocytes (TILs) in breast cancer, including recommendations to assess TILs in residual disease after neoadjuvant therapy and in carcinoma in situ: A report of the International Immuno-Oncology Biomarker Working Group on Breast Cancer. Semin Cancer Biol. 2018 Oct;52(Pt 2):16-25.

14 Demaria S, Volm MD, Shapiro RL, Yee HT, Oratz R, Formenti SC, et al: Development of tumor-infiltrating lymphocytes in breast cancer after neoadjuvant paclitaxel chemotherapy. Clin Cancer Res. 2001;7:3025-30.

15 Ladoire S, Arnould L, Apetoh L, Coudert B, Martin F, Chauffert B, et al: Pathologic Complete Response to Neoadjuvant Chemotherapy of Breast Carcinoma Is Associated with the Disappearance of Tumor-Infiltrating Foxp3+ Regulatory T Cells. Clin Cancer Res. 2008;14: 2413-20. 
16 Kristensen VN, Vaske CJ, Ursini-Siegel J, Van Loo P, Nordgard SH, Sachidanandam R, et al. Integrated molecular profiles of invasive breast tumors and ductal carcinoma in situ (DCIS) reveal differential vascular and interleukin signaling. Proc Natl Acad Sci USA. 2012 Feb;109(8):2802-7.

17 DeNardo DG, Brennan DJ, Rexhepaj E, Ruffell B, Shiao SL, Madden SF, et al. Leukocyte complexity predicts breast cancer surviv$\mathrm{al}$ and functionally regulates response to chemotherapy. Cancer Discov. 2011 Jun;1(1): 54-67.

18 Emens LA. Breast cancer immunobiology driving immunotherapy: vaccines and immune checkpoint blockade. Expert Rev Anticancer Ther. 2012 Dec;12(12):1597-611.

19 Yamaguchi R, Tanaka M, Yano A, Tse GM, Yamaguchi M, Koura K, et al. Tumor-infiltrating lymphocytes are important pathologic predictors for neoadjuvant chemotherapy in patients with breast cancer. Hum Pathol. 2012 Oct;43(10):1688-94.

20 Van Berckelaer C, Rypens C, van Dam P, Pouillon L, Parizel M, Schats KA, et al. Infiltrating stromal immune cells in inflammatory breast cancer are associated with an improved outcome and increased PD-L1 expression. Breast Cancer Res. 2019 Feb;21(1):28.

21 Ono M, Tsuda H, Shimizu C, Yamamoto S, Shibata T, Yamamoto H, et al. Tumor-infiltrating lymphocytes are correlated with response to neoadjuvant chemotherapy in triple-negative breast cancer. Breast Cancer Res Treat. 2012 Apr;132(3):793-805.

22 Oda N, Shimazu K, Naoi Y, Morimoto K, Shimomura $A$, Shimoda $M$, et al. Intratumoral regulatory $\mathrm{T}$ cells as an independent predictive factor for pathological complete response to neoadjuvant paclitaxel followed by $5-\mathrm{FU} /$ epirubicin/cyclophosphamide in breast cancer patients. Breast Cancer Res Treat. 2012 Nov;136(1):107-16.

23 Masuda H, Baggerly KA, Wang Y, Iwamoto T, Brewer T, Pusztai L, et al. Comparison of molecular subtype distribution in triple-negative inflammatory and non-inflammatory breast cancers. Breast Cancer Res. 2013 Nov; 15(6):R112

24 Lehmann BD, Bauer JA, Chen X, Sanders ME, Chakravarthy AB, Shyr Y, et al. Identification of human triple-negative breast cancer subtypes and preclinical models for selection of targeted therapies. J Clin Invest. $2011 \mathrm{Jul}$; 121(7):2750-67.

25 Lehmann BD, Jovanović B, Chen X, Estrada MV, Johnson KN, Shyr Y, et al. Refinement of Triple-Negative Breast Cancer Molecular Subtypes: Implications for Neoadjuvant Chemotherapy Selection. PLoS One. 2016 Jun; 11(6): 0157368.

26 Ingold Heppner B, Untch $M$, Denkert C, Pfitzner BM, Lederer B, Schmitt W, et al. Tumor-Infiltrating Lymphocytes: A Predictive and Prognostic Biomarker in NeoadjuvantTreated HER2-Positive Breast Cancer. Clin Cancer Res. 2016 Dec;22(23):5747-54.
27 Matikas A, Lövrot J, Ramberg A, Eriksson $\mathrm{M}$, Lindsten T, Lekberg T, et al. Dynamic evaluation of the immune infiltrate and immune function genes as predictive markers for neoadjuvant chemotherapy in hormone receptor positive, HER2 negative breast cancer. OncoImmunology. 2018 Jul;7(9): e1466017.

28 Symmans WF, Peintinger F, Hatzis C, Rajan $\mathrm{R}$, Kuerer $\mathrm{H}$, Valero V, et al. Measurement of residual breast cancer burden to predict survival after neoadjuvant chemotherapy. J Clin Oncol. 2007 Oct;25(28):4414-22.

29 MD Anderson Cancer Center's online calculator [Internet]. Accessed 2014. Available from: http://www3.mdanderson.org/app/ medcalc/index.cfm? pagename $=$ jsconvert 3

30 Sheri A, Smith IE, Johnston SR, A'Hern R, Nerurkar A, Jones RL, et al. Residual proliferative cancer burden to predict long-term outcome following neoadjuvant chemotherapy. Ann Oncol. 2015 Jan;26(1):75-80.

31 Criscitiello C, Bayar MA, Curigliano G, Symmans FW, Desmedt C, Bonnefoi H, et al. A gene signature to predict high tumor-infiltrating lymphocytes after neoadjuvant chemotherapy and outcome in patients with triple-negative breast cancer. Ann Oncol. 2018 Jan;29(1):162-9.

32 Loi S, Dushyanthen S, Beavis PA, Salgado R, Denkert C, Savas P, et al. RAS/MAPK Activation Is Associated with Reduced Tumor-Infiltrating Lymphocytes in Triple-Negative Breast Cancer: Therapeutic Cooperation between MEK and PD-1/PD-L1 Immune Checkpoint Inhibitors. Clin Cancer Res. 2016 Mar;22(6):1499-509.

33 Hamy AS, Pierga JY, Sabaila A, Laas E, Bonsang-Kitzis H, Laurent C, et al. Stromal lymphocyte infiltration after neoadjuvant chemotherapy is associated with aggressive residual disease and lower disease-free survival in HER2-positive breast cancer. Ann Oncol. 2017 Sep;28(9):2233-40.

34 Asano Y, Kashiwagi S, Goto W, Takada K, Takahashi K, Hatano T, et al. Prediction of survival after neoadjuvant chemotherapy for breast cancer by evaluation of tumor-infiltrating lymphocytes and residual cancer burden. BMC Cancer. 2017 Dec;17(1):888.

35 Luen SJ, Salgado R, Dieci MV, Vingiani A, Curigliano G, Gould RE, et al. Prognostic implications of residual disease tumor-infiltrating lymphocytes and residual cancer burden in triple-negative breast cancer patients after neoadjuvant chemotherapy. Ann Oncol. 2019 Feb;30(2):236-42.

36 Brown JR, Wimberly H, Lannin DR, Nixon C, Rimm DL, Bossuyt V: Multiplexed quantitative analysis of $\mathrm{CD} 3, \mathrm{CD} 8$, and $\mathrm{CD} 20$ predicts response to neoadjuvant chemotherapy in breast cancer. Clin Cancer Res. 2014;20: 5995-6005.

37 Seo AN, Lee HJ, Kim EJ, Kim HJ, Jang MH, Lee HE, et al. Tumour-infiltrating CD8+ lymphocytes as an independent predictive factor for pathological complete response to prima- ry systemic therapy in breast cancer. Br J Cancer. 2013 Nov;109(10):2705-13.

38 Asano Y, Kashiwagi S, Goto W, Kurata K, Noda S, Takashima T, et al. Tumour-infiltrating CD8 to FOXP3 lymphocyte ratio in predicting treatment responses to neoadjuvant chemotherapy of aggressive breast cancer. $\mathrm{Br}$ J Surg. 2016 Jun;103(7):845-54.

39 Miyashita M, Sasano H, Tamaki K, Hirakawa $\mathrm{H}$, Takahashi Y, Nakagawa S, et al. Prognostic significance of tumor-infiltrating CD8+ and FOXP3+ lymphocytes in residual tumors and alterations in these parameters after neoadjuvant chemotherapy in triple-negative breast cancer: a retrospective multicenter study. Breast Cancer Res. 2015 Sep;17(1):124.

40 Goto W, Kashiwagi S, Asano Y, Takada K, Takahashi K, Hatano T, et al. Predictive value of improvement in the immune tumour microenvironment in patients with breast cancer treated with neoadjuvant chemotherapy. ESMO Open. 2018 Aug;3(6):e000305-000305.

41 García-Martínez E, Gil GL, Benito AC, González-Billalabeitia E, Conesa MA, García García $T$, et al. Tumor-infiltrating immune cell profiles and their change after neoadjuvant chemotherapy predict response and prognosis of breast cancer. Breast Cancer Res. 2014 Nov; 16(6):488.

42 Arias-Pulido H, Cimino-Mathews A, Chaher $\mathrm{N}$, Qualls C, Joste N, Colpaert C, et al. The combined presence of $\mathrm{CD} 20+\mathrm{B}$ cells and $\mathrm{PD}$ $\mathrm{L} 1+$ tumor-infiltrating lymphocytes in inflammatory breast cancer is prognostic of improved patient outcome. Breast Cancer Res Treat. 2018 Sep;171(2):273-82.

43 Hou Y, Nitta H, Wei L, Banks PM, Parwani AV, Li Z. Evaluation of Immune Reaction and PD-L1 Expression Using Multiplex Immunohistochemistry in HER2-Positive Breast Cancer: The Association with Response to AntiHER2 Neoadjuvant Therapy. Clin Breast Cancer. 2018 Apr;18(2):e237-44.

44 Verma C, Kaewkangsadan V, Eremin JM, Cowley GP, Ilyas M, El-Sheemy MA, et al. Natural killer (NK) cell profiles in blood and tumour in women with large and locally advanced breast cancer (LLABC) and their contribution to a pathological complete response (PCR) in the tumour following neoadjuvant chemotherapy (NAC): differential restoration of blood profiles by NAC and surgery. J Transl Med. 2015 Jun;13(1):180.

45 Kim R, Kawai A, Wakisaka M, Funaoka Y, Yasuda N, Hidaka M, et al. A potential role for peripheral natural killer cell activity induced by preoperative chemotherapy in breast cancer patients. Cancer Immunol Immunother. 2019 Apr;68(4):577-85.

46 Muraro E, Comaro E, Talamini R, Turchet E, Miolo G, Scalone S, et al. Improved Natural Killer cell activity and retained anti-tumor CD8(+) T cell responses contribute to the induction of a pathological complete response in HER2-positive breast cancer patients undergoing neoadjuvant chemotherapy. J Transl Med. 2015 Jun;13(1):204. 
47 Ascierto ML, Idowu MO, Zhao Y, Khalak H, Payne KK, Wang XY, et al. Molecular signatures mostly associated with NK cells are predictive of relapse free survival in breast cancer patients. J Transl Med. 2013 Jun; 11(1): 145 .

48 Garcia-Chagollan M, Carranza-Torres IE, Carranza-Rosales P, Guzmán-Delgado NE, Ramírez-Montoya $\mathrm{H}$, Martínez-Silva MG, et al. Expression of NK Cell Surface Receptors in Breast Cancer Tissue as Predictors of Resistance to Antineoplastic Treatment. Technol Cancer Res Treat. 2018 Jan; 17: 1533033818764499.

49 Muntasell A, Rojo F, Servitja S, Rubio-Perez C, Cabo M, Tamborero D, et al: NK cell infiltrates and HLA class I expression in primary HER2 + breast cancer predict and uncouple pathological response and disease-free survival. Clin Cancer Res. 2019;25(5):1535-45.

50 Gordon S. Alternative activation of macrophages. Nat Rev Immunol. 2003 Jan;3(1):2335.

51 Leek RD, Lewis CE, Whitehouse R, Greenall M, Clarke J, Harris AL. Association of macrophage infiltration with angiogenesis and prognosis in invasive breast carcinoma. Cancer Res. 1996 Oct;56(20):4625-9.

52 Tang X. Tumor-associated macrophages as potential diagnostic and prognostic biomarkers in breast cancer. Cancer Lett. 2013 May; 332(1):3-10.

53 Williams CB, Yeh ES, Soloff AC. Tumor-associated macrophages: unwitting accomplices in breast cancer malignancy. NPJ Breast Cancer. 2016;2(1):15025.

54 Medrek C, Pontén F, Jirström K, Leandersson $\mathrm{K}$. The presence of tumor associated macrophages in tumor stroma as a prognostic marker for breast cancer patients. BMC Cancer. 2012 Jul;12(1):306.

55 Gwak JM, Jang MH, Kim DI, Seo AN, Park SY. Prognostic value of tumor-associated macrophages according to histologic locations and hormone receptor status in breast cancer. PLoS One. 2015 Apr; 10(4):e0125728.

56 Mitrofanova I, Zavyalova M, Telegina N, Buldakov M, Riabov V, Cherdyntseva N, et al. Tumor-associated macrophages in human breast cancer parenchyma negatively correlate with lymphatic metastasis after neoadjuvant chemotherapy. Immunobiology. 2017 Jan;222(1):101-9.

57 Kaewkangsadan V, Verma C, Eremin JM, Cowley G, Ilyas M, Satthaporn S, et al. The Differential Contribution of the Innate Immune System to a Good Pathological Response in the Breast and Axillary Lymph Nodes Induced by Neoadjuvant Chemotherapy in Women with Large and Locally Advanced Breast Cancers. J Immunol Res. 2017; 2017:1049023.

58 Sbarra AJ. In Klebanoff SJ, Clark RA, editors. The neutrophil: function and clinical disorders. Amsterdam, New York and Oxford: Elsevier/North-Holland Biomedical Press; 1978.
59 Antonio N, Bønnelykke-Behrndtz ML, Ward LC, Collin J, Christensen IJ, Steiniche T, et al. The wound inflammatory response exacerbates growth of pre-neoplastic cells and progression to cancer. EMBO J. 2015 Sep;34(17): 2219-36.

60 Benelli R, Morini M, Carrozzino F, Ferrari N, Minghelli S, Santi L, et al. Neutrophils as a key cellular target for angiostatin: implications for regulation of angiogenesis and inflammation. FASEB J. 2002 Feb;16(2):267-9.

61 Chen J, Deng Q, Pan Y, He B, Ying H, Sun H, et al. Prognostic value of neutrophil-to-lymphocyte ratio in breast cancer. FEBS Open Bio. 2015 May;5(1):502-7.

62 Azab B, Bhatt VR, Phookan J, Murukutla S, Kohn N, Terjanian T, et al. Usefulness of the neutrophil-to-lymphocyte ratio in predicting short- and long-term mortality in breast cancer patients. Ann Surg Oncol. 2012 Jan;19(1): 217-24.

63 Ozyalvacli G, Yesil C, Kargi E, Kizildag B, Kilitci A, Yilmaz F. Diagnostic and prognostic importance of the neutrophil lymphocyte ratio in breast cancer. Asian Pac J Cancer Prev. 2014;15(23):10363-6.

64 Idoyaga J, Lubkin A, Fiorese C, Lahoud MH, Caminschi I, Huang Y, et al. Comparable T helper 1 (Th1) and CD8 T-cell immunity by targeting HIV gag p24 to CD8 dendritic cells within antibodies to Langerin, DEC205, and Clec9A. Proc Natl Acad Sci USA. 2011 Feb; 108(6):2384-9.

65 Gabrilovich DI, Ishida T, Nadaf S, Ohm JE, Carbone DP: Antibodies to vascular endothelial growth factor enhance the efficacy of cancer immunotherapy by improving endogenous dendritic cell function. Clin Cancer Res. 1999;5:2963-70.

66 Bell D, Chomarat P, Broyles D, Netto G, Harb $\mathrm{GM}$, Lebecque $S$, et al. In breast carcinoma tissue, immature dendritic cells reside within the tumor, whereas mature dendritic cells are located in peritumoral areas. J Exp Med. 1999 Nov;190(10):1417-26.

67 Tsuge T, Yamakawa M, Tsukamoto M. Infiltrating dendritic/Langerhans cells in primary breast cancer. Breast Cancer Res Treat. 2000 Jan;59(2):141-52.

68 Hillenbrand EE, Neville AM, Coventry BJ. Immunohistochemical localization of CD1apositive putative dendritic cells in human breast tumours. Br J Cancer. 1999 Feb;79(56):940-4.

69 Lespagnard L, Gancberg D, Rouas G, Leclercq G, de Saint-Aubain Somerhausen N, Di Leo A, et al. Tumor-infiltrating dendritic cells in adenocarcinomas of the breast: a study of 143 neoplasms with a correlation to usual prognostic factors and to clinical outcome. Int J Cancer. 1999 Jun;84(3):309-14.

70 Iwamoto $M$, Shinohara $H$, Miyamoto $A$, Okuzawa M, Mabuchi H, Nohara T, et al. Prognostic value of tumor-infiltrating dendritic cells expressing CD83 in human breast carcinomas. Int J Cancer. 2003 Mar;104(1): 92-7.
71 Lee H, Lee HJ, Song IH, Bang WS, Heo SH, Gong G, et al. CD11c-Positive Dendritic Cells in Triple-negative Breast Cancer. In Vivo. 2018 Nov-Dec;32(6):1561-9.

72 Loi S DD, Adams S, Pruneri G, Francis PA, Lacroix-Triki M, Joensuu H, Vittoria Dieci M, Badve S, Demaria S, Gray R, Munzone E, Lemonnier J, Sotiriou C, Piccart MJ, KellokumpuLehtinen PL, Vingiani A, Gray K, Andre F, Denkert C, Salgado R, Michiels S.: Tumor infiltrating lymphocytes and prognosis: a pooled individual patient analysis of 2148 early-stage triple negative breast cancers Manuscript is accepted in the journal of clinical oncology 2018

73 Campbell MJ, Baehner F, O'Meara T, Ojukwu E, Han B, Mukhtar R, et al. Characterizing the immune microenvironment in high-risk ductal carcinoma in situ of the breast. Breast Cancer Res Treat. 2017 Jan;161(1):17-28.

74 Thompson E, Taube JM, Elwood H, Sharma R, Meeker A, Warzecha HN, et al. The immune microenvironment of breast ductal carcinoma in situ. Mod Pathol. 2016;29:249-58.

75 Pruneri G, Lazzeroni M, Bagnardi V, Tiburzio GB, Rotmensz N, DeCensi A, et al. The prevalence and clinical relevance of tumor-infiltrating lymphocytes (TILs) in ductal carcinoma in situ of the breast. Ann Oncol. 2017 Feb; 28(2):321-8.

76 Toss MS, Miligy I, Al-Kawaz A, Alsleem M, Khout H, Rida PC, et al. Prognostic significance of tumor-infiltrating lymphocytes in ductal carcinoma in situ of the breast. Mod Pathol. 2018;31:1226-36.

77 Dano H, Altinay S, Arnould L, Bletard N, Colpaert C, Dedeurwaerdere F, et al. Interobserver variability in upfront dichotomous histopathological assessment of ductal carcinoma in situ of the breast: the DCISion study. Mod Pathol. 2019. DOI: 10.1038/s41379-019-0367-9.

78 Badr NM, Asaad N, Abd Elwahed MM, Abdou AG, Serag El Din MM, Hoar F, et al. Assessment of Tumour Microenvironment Immune Cell Profile in Inflammatory Breast Carcinoma Using Digital Multiplex Analysis. J Pathol. 2018.

79 Schmid P, Adams S, Rugo HS, Schneeweiss A, Barrios CH, Iwata $\mathrm{H}$, et al.; IMpassion 130 Trial Investigators. Atezolizumab and Nab-Paclitaxel in Advanced Triple-Negative Breast Cancer. N Engl J Med. 2018 Nov;379(22):2108-21.

80 Hornychova $\mathrm{H}$, Melichar B, Tomsova M, Mergancova J, Urminska H, Ryska A. Tumorinfiltrating lymphocytes predict response to neoadjuvant chemotherapy in patients with breast carcinoma. Cancer Invest. 2008 Dec; 26(10):1024-31.

81 Lee HJ, Seo JY, Ahn JH, Ahn SH, Gong G. Tumor-associated lymphocytes predict response to neoadjuvant chemotherapy in breast cancer patients. J Breast Cancer. 2013 Mar;16(1):32-9.

82 Miyashita M, Sasano H, Tamaki K, Chan M, Hirakawa H, Suzuki A, et al. Tumor-infiltrating $\mathrm{CD} 8+$ and FOXP3+ lymphocytes in triple-negative breast cancer: its correlation with pathological complete response to neoadjuvant chemotherapy. Breast Cancer Res Treat. 2014 Dec;148(3):525-34. 
83 Bianchini G, Pusztai L, Pienkowski T, Im YH, Bianchi GV, Tseng LM, et al. Immune modulation of pathologic complete response after neoadjuvant HER2-directed therapies in the NeoSphere trial. Ann Oncol. 2015 Dec; 26(12):2429-36.

84 Ali HR, Dariush A, Provenzano E, Bardwell $\mathrm{H}$, Abraham JE, Iddawela M, et al. Computational pathology of pre-treatment biopsies identifies lymphocyte density as a predictor of response to neoadjuvant chemotherapy in breast cancer. Breast Cancer Res. 2016 Feb; 18(1):21-21.

85 Ibrahiem A, Mouhamed H, Anter A. Predictive significance of stromal-associated lymphocytes in response to neoadjuvant chemotherapy in breast cancer. Menoufia Med J. 2017;30:1168-77.

86 Al-Saleh K, Abd El-Aziz N, Ali A, Abozeed W, Abd El-Warith A, Ibraheem A, et al. Predictive and prognostic significance of CD8+ tumor-infiltrating lymphocytes in patients with luminal B/HER 2 negative breast cancer treated with neoadjuvant chemotherapy. Oncol Lett. 2017 Jul;14(1):337-44.

87 Siregar KB, Pane J, Siburian R; Adam Malik General Hospital. Correlation between Tumor-Infiltrating Lymphocytes and Pathological Response in Locally Advanced Breast Cancer Patients Who Received Neoadjuvant Chemotherapy in H. Case Rep Oncol. 2017 Aug; 10(2):699-705.

88 Pelekanou V, Carvajal-Hausdorf DE, Altan M, Wasserman B, Carvajal-Hausdorf C, Wimberly $\mathrm{H}$, et al. Effect of neoadjuvant chemotherapy on tumor-infiltrating lymphocytes and PD-L1 expression in breast cancer and its clinical significance. Breast Cancer Res. 2017 Aug;19(1):91.
89 Cha YJ, Ahn SG, Bae SJ, Yoon CI, Seo J, Jung $\mathrm{WH}$, et al. Comparison of tumor-infiltrating lymphocytes of breast cancer in core needle biopsies and resected specimens: a retrospective analysis. Breast Cancer Res Treat. 2018; 171:295-302.

90 Asano Y, Kashiwagi S, Goto W, Takada K, Takahashi K, Hatano T, et al. Prediction of Treatment Response to Neoadjuvant Chemotherapy in Breast Cancer by Subtype Using Tumor-infiltrating Lymphocytes. Anticancer Res. 2018 Apr;38(4):2311-21.

91 Elsayed ZM, Elkady MS, Elmmonem Biomy WA, Ezz El Din MM, El Mahdy MM, Omran TI, et al. Predictive and Prognostic Impact of Tumor-Infiltrating Lymphocytes (CD8+) in Breast Cancer Treated with Neoadjuvant Chemotherapy. Egypt J Hosp Med. 2018;72: 5466-9.

92 Eryilmaz MK, Mutlu H, Ünal B, Salim DK, Musri FY, Coşkun HS. The importance of stromal and intratumoral tumor lymphocyte infiltration for pathologic complete response in patients with locally advanced breast cancer. J Cancer Res Ther. 2018 Apr-Jun;14(3): 619-24.

93 Denkert C, von Minckwitz G, Darb-Esfahani $\mathrm{S}$, Lederer B, Heppner BI, Weber KE, et al. Tumour-infiltrating lymphocytes and prognosis in different subtypes of breast cancer: a pooled analysis of 3771 patients treated with neoadjuvant therapy. Lancet Oncol. 2018 Jan; 19(1):40-50.
94 Ruan M, Tian T, Rao J, Xu X, Yu B, Yang W, et al. Predictive value of tumor-infiltrating lymphocytes to pathological complete response in neoadjuvant treated triple-negative breast cancers. Diagn Pathol. 2018;13:66.

95 Miyoshi $\mathrm{Y}$, Shien T, Ogiya A, Ishida N, Yamazaki K, Horii R, et al. Associations in tumor infiltrating lymphocytes between clinicopathological factors and clinical outcomes in estrogen receptor-positive/human epidermal growth factor receptor type 2 negative breast cancer. Oncol Lett. 2019 Feb;17(2): 2177-86.

96 de Groot AF, Blok EJ, Charehbili A, Engels CC, Smit VT, Dekker-Ensink NG, et al. Strong CD8+ lymphocyte infiltration in combination with expression of HLA class I is associated with better tumor control in breast cancer patients treated with neoadjuvant chemotherapy. Breast Cancer Res Treat. 2019 Jun;175(3):605-15

97 Kurozumi S, Inoue K, Matsumoto H, Fujii T, Horiguchi J, Oyama T, et al. Prognostic utility of tumor-infiltrating lymphocytes in residual tumor after neoadjuvant chemotherapy with trastuzumab for HER2-positive breast cancer. Sci Rep. 2019 Feb;9(1):1583.

98 Russo L, Maltese A, Betancourt L, Romero G, Cialoni D, De la Fuente L, et al. Locally advanced breast cancer: tumor-infiltrating lymphocytes as a predictive factor of response to neoadjuvant chemotherapy. Eur J Surg Oncol. 2019;45:963-8. 